ISSN: 2349-2031

Research Article

\title{
Teachers' Perceptions on Integration of Information Communication Technology in Teaching and learning in Secondary Schools in Uasin Gishu County, Kenya
}

\author{
Ogoti Evans Okendo \\ $(\mathrm{PhD})$ Senior Lecturer Department Of Education Curriculum And Instruction \\ Mwenge Catholic University P.O Box 1226, Moshi Tanzania
}

\begin{abstract}
The purpose of the study was to establish teachers' perception on integration of information communication technology in teaching and learning in secondary schools in Uasin Gishu County. The study was guided by the Minimalism theory. The study utilized ex post facto research design. The target population included all private and public secondary schools in Uasin Gishu County and all teachers in private and public secondary schools in the county. Stratified and simple random sampling procedures were to select the respondents for the study. The study utilized questionnaire and observation schedules for data collection. The study concluded that most of teachers in public and private secondary schools in Uasin Gishu County had favorable perceptions of availability of ICT infrastructure in their school, The study further concluded that both private and public secondary teachers in Uasin Gishu County had favorable perceptions of availability of plans for ICT integration in teaching in their school and that there is a significant relationship between public and private secondary teachers mean perception scores on ICT integration in Uasin Gishu County. the study recommended that the county Government of Uasin Gishu should provide ICT infrastructure in both private and public secondary schools and The principals and school managers in Uasin Gishu County should develop ICT integration plans at the school level which should inform the process of integrating the same in classroom teaching and learning.
\end{abstract}

Keywords: Information communication Technology, teaching and learning, private and public secondary schools

\section{Introduction}

ICT stand for information and communication technologies and is defined, as a "diverse set of technological tools and resources used to communicate, and to create, disseminate, store, and manage information." "ICT implies the technology which consists of electronic devices and associated human interactive materials that enable the user to employ them for a wide range of teaching - learning processes in addition to personal use." .(Rabah,2009) These technologies include computers, the Internet, broadcasting technologies (radio and television), and telephony. "ICT is that technology which uses the information to meet human need or purposes including processing and exchanging." "Information and communications technology (ICT) in education is the processing of information and its communications facilities and features that variously support teaching, learning and a range of activities in education." (Rabah, 2009)

Although there are several strategies outlined in the ICT policy those touching on the curriculum and training of teachers in ICT skills and pedagogical applications of ICT seem to have been singled out as basic to the implementation of ICT. The vision of the Kenyan government is to facilitate ICT as a universal tool for education and training. Moreover, according to the Elimu network (2008) \& UNESCO (2008). The need to effectively embrace and facilitate technology supported learning cannot be overemphasized. Kenya's biggest impediment to integrating ICT in education. Particularly at secondary level, is her technologically challenged teachers, According to Mukubwa (2013). Sixty per cent of secondary teachers lack the requisite ICT competence and skills to implement the government's programme on ICT integration in teaching and learning.

According to Hennesy \& Onguko (2010) Majority of Kenyan teachers are ill equipped to effectively integrate ICT in teaching and the main challenges for teachers can be attributed to lack of adequate number of computers, educational application, training, policy implementation and strategy on how integration should be done. It is also worth noting that low investment on ICT infrastructure coupled with high cost of connectivity and bandwidth, poor technology infrastructure, lack of electricity and frequent power outages are also some of the major problems hindering use of resources available on the internet.

ICT if implemented can help in the achievement of the Millennium Development Goals through three basic Processes: enhancing livelihoods, improved efficiency in the delivery of services (in secondary schools), and allowing stakeholders (Board of governors, parents- Board) a voice in the planning process. Heeks (2006) ICT advances brought about by the private sector can also complement initiatives undertaken by government or development cooperation agencies. Two factors will be vital in allowing these benefits to unfold: the development of capacity in ICT use; and the generation of suitable content, established not by the ICT sector but by the lead sector in question - health, education, 
governance. Another factor that influences students 'learning is students 'capabilities at a particular age. Heeks (2006)

According to Shield (2000), the learning task should be tailored to the students 'capabilities rather than the students having to fit in the software designer's generalized understanding of how learning should take placell. This means that in order for the learning process to smoothly lead to the desired learning outcome, teachers should be very helpful when employing texts, reference sources, multimedia and communication tools (Shield, 2000), as they have to adopt them to pupils' learning capabilities. Reports from World Bank (2002) stipulate that poverty, and not ICTs, is the primary bottleneck to ICT development initiatives in most developing countries. ICTs act as an amplifier for such underlying processes, and what makes development function well, can be made to function better using ICTs. Needless to say, ICTs are dependent on national policy, the regulation of broadcasting licenses, and on the ensuing skills required to use and manage this industry, Heeks (2006)

The role of the teachers is, for a given group of students, to provide educational technology activities of an appropriate level of difficulty based on their cognitive abilities (age, fast vs. slow learners), that are expressed in a variety of ways (i.e.: multimedia, the Internet, etc.), in order to adjust the curriculum to a variety of learning styles (visual, audio, bydoing) expressed through project based activities based on the active learning approach. Additionally, teachers have to provide a plethora of learning strategies in order for the students to learn how to select the one that is most appropriate for their desired learning outcome. Based on Stables (1997), what is most important in this process is for the children to express and to develop their own ideas. Teachers are there to facilitate this process and to identify where the learning blockage occurs, in order to facilitate the learning process, Based on Stables (1997). If we measure learning as the amount of information people can recall after learning has taken place, studies have shown that people can recall $20 \%$ of what they have heard, $30 \%$ of what they have seen, $50 \%$ of what they have experienced and nearly $90 \%$ of what they have heard, seen and experienced simultaneously. These percentages are certainly not rigid, as each individual has a learning style of his own. Based on this, he/she learns better by hearing (audio learners), by seeing (visual learners) or by doing (kinaesthetic learners), sanja, Mneri, Ogoti,,Tenge.,\& Nasiuma,(2014). The advantage of teaching with multimedia technology is that it covers all the learning styles at the same time, as it combines text, sound and interactivity of the user with the program. This is considered as the main advantage of teaching with technology over the traditional method of instruction, Stables (1997)

\section{Research questions}

1. What is the perception of secondary school teachers in Uasin Gishu County on the availability of ICT infrastructure at their schools?
2. What is the perception of secondary school teachers in Uasin Gishu County on the availability of plans for ICT integration in teaching at their schools?

3. To what extent are public and private secondary school teachers in Uasin Gishu County competent in integrating ICT in teaching?

\section{Hypothesis}

HO: There is no significant relationship between public and private secondary teachers mean perception scores on ICT integration in Uasin Gishu County

\section{Theoretical framework}

The study was guided by the Minimalism theory which according to Carrol (1990), was developed to explain how people learn to use a diverse range of computer application including word processing, databases and programming. The theory points out and emphasizes the necessity to build upon the learner's experience. The theory suggests that (1) all learning activities should be meaningful and self-contained activities, (2) learners should be given realistic projects as quickly as possible (3) instruction should permit self-directed reasoning and improvising by increasing the number of active learning activities, (4) training materials and activities should provide for error recognition and recovery, and (5) there should be close linkage between the training and actual system. The theory holds that new users are always learning computer methods in the context of specific pre-existing goals and expectations. Therefore, the theory finds applicability in the study within the context of empowering teachers with ICT skills and competencies specific to and appropriate for integration. The theory resonates well with the aspect of teacher capacity building and is applicable in the sense that secondary teachers have pre-existing goals and expectations; that is acquiring specific ICT skills and competencies to enable them effectively integrate the same in teaching it can also be applied by taking teachers through meaningful tasks and computer applications that are relevant to teaching.

\section{Research Methodology}

The study utilized ex post facto research design to obtain quantitative data that answered the research question. The target population included all private and public secondary schools in Uasin Gishu County and all teachers in private and public secondary schools in the county. Stratified and simple random sampling procedures were used to select six (6) teachers drawn from each of the twenty four sampled schools in the county. 12 private and 12 public secondary school. Making a sample size of 144 respondents. The study utilized questionnaire and observation schedule for data collection. The data was analyzed using the Statistical Package for Social Sciences (SPSS).

\section{Discussion of Research Findings}

Perceptions of secondary school teachers in Uasin Gishu County on the availability of ICT infrastructure at their 
Ogoti Evans Okendo / Teachers' Perceptions on Integration of Information Communication Technology in Teaching and learning in Secondary Schools in Uasin Gishu County, Kenya

schools

The first research question of this study was to determine the teachers' perceptions on the availability of ICT infrastructure

items of the questionnaires administered to 144 teachers and an observation schedule for the 24 schools. The results were in their schools. This was established through the perceptions summarized and presented are presented in Table 1

Table 1. Perceptions of secondary school teachers in Uasin Gishu County on the availability of ICT infrastructure at their schools $(\mathbf{N}=144)$

\begin{tabular}{lll}
\hline Perception statement & Mean & $\begin{array}{c}\text { Standard } \\
\text { deviation }\end{array}$ \\
\hline 1 Computers and projectors are available at your school & 2.231 & 0.742 \\
2. Electricity is easily available at school & 4.211 & 1.225 \\
3 The supply of electricity is reliable & 2.732 & 0.320 \\
4. The computers, projectors and videos are in functioning condition & 2.652 & 0.416 \\
5. Computers, projectors and videos are adequate & 2.421 & 0.312 \\
6. The schools has a video and computer lab that is adequate & 3.427 & 0.042 \\
7. The computer lab has internet facilities & 1.471 & 0.263 \\
8. The school has a television and radio for educational use & 4.125 & 0.675 \\
9. the school television and radio are in functioning condition & 41.06 & 0.351
\end{tabular}

The results of table 1 indicate that generally teachers' had favorable perceptions of availability of ICT infrastructure in their school with four out nine items having a mean of 3.000 and above, The study further found out that in a number of schools in the county the computers and projectors were not available, supply of electricity was not reliable, the computers, projectors and videos were not in functioning condition and most of the computer labs had no internet facilities. This findings agree with Chigona \& Chigona (2010) who conducted an investigation of factors affecting the use of ICT for teaching in the Westren Cape schools. The research findings revealed that there are a number of factors (personal, social and environmental) which are preventing the educators from realizing their potential capabilities from the use of ICT resources.

Perception of secondary school teachers in Uasin Gishu County on the availability of plans for ICT integration in teaching at their schools

The second research question of this study was to determine the teachers' perceptions on the availability of plans for ICT integration in teaching and learning in their schools. This was established through the perceptions items of the questionnaires administered to 144 teachers and an observation schedule for the 24 schools. The results were summarized and presented are presented in Table 2

Table 2 Perception of secondary school teachers in Uasin Gishu County on the availability of plans for ICT integration in teaching at their school

\begin{tabular}{lll}
\hline Perception statement & Mean & $\begin{array}{c}\text { Standard } \\
\text { deviation }\end{array}$ \\
\hline 1 The school has plans for integrating ICT in classroom instruction & 2.628 & 0.502 \\
2. The schools strictly ensures the plans are adhered for integration & 2.453 & 3.213 \\
3 The plans are clearly understood by teachers & 4.211 & 0.421 \\
4. The plans for ICT integration in teaching are easily implementable & 3.213 & 0.425 \\
5. Teachers at your school frequently use ICT to teach their subjects & 2.723 & 0.672 \\
6. There is adequate digital content on subject taught by teachers & 3.512 & 0.412 \\
7. principals frequently monitor lessons to ensure ICT is used to teach them & 4.321 & 0.942 \\
8.learners interact with ICT tools in the classroom for learning purpose & 3.342 & 0.421 \\
9. ICT integration strategy is captured in the school strategic plan & 0.610 \\
10. The school has set aside funds for the integration process of ICT in teaching & 2.453 & 0.472
\end{tabular}

The results of Table 2 indicate that generally teachers' had favorable perceptions of availability of plans for ICT integration in teaching in their school with six out of nine items having a mean of 3.000 and above, The study further found out that in a number of schools in the county have no plans for integrating ICT in classroom instruction, schools do not strictly ensure that integration of ICT plans are adhered to, there are no adequate digital content on subject taught by teachers and schools have not set aside funds for the integration process of ICT in teaching. 
Ogoti Evans Okendo / Teachers' Perceptions on Integration of Information Communication Technology in Teaching and learning in Secondary Schools in Uasin Gishu County, Kenya

Extent to which public and private secondary school teachers in Uasin Gishu County are competent in integrating ICT in teaching

The third research question of this study was to establish the extent to which public and private secondary teachers in Uasin
Gishu County are competent in integrating ICT in teaching. This was established through the perceptions items of the questionnaires administered to 144 teachers and an observation schedule for the 24 schools. The results were summarized and presented are presented in Table 3

Table 3 Extent to which public and private secondary school teachers in Uasin Gishu County are competent in integrating ICT in teaching

\begin{tabular}{lll}
\hline Perception statement & Mean & $\begin{array}{c}\text { Standard } \\
\text { deviation }\end{array}$ \\
\hline 1 Teachers frequently integrate ICT in teaching their subjects & 2.467 & 0.321 \\
2. There is adequate digital content in the subjects taught by teachers & 3.753 & 0.644 \\
3 Principals frequently monitor lessons to ensure ICT is used to teach lessons & 2.665 & 0.521 \\
4. Learners in school interact with ICT tools in the classrooms for learning purpose & 4.101 & 0.435 \\
5. Teachers prepare their lesson content by integrating ICT materials in their lesson & 3.436 \\
6. Teachers prepare lessons materials using on line resources & \\
7. Teachers deliver lessons using power points projectors & 2.322 \\
8. Most teachers in my schools have basic computer skills & 2.612 \\
9. ICT integration strategy is understood by most teachers in my school & 4.224 & 0.378 \\
10. my school has set aside funds for the integration process of ICT in teaching & 3.342 & 0.311 \\
& 2.954 & 0.502 \\
\hline
\end{tabular}

The results in Table 3 that private and public secondary teachers in Uasin Gishu County are generally competent in integrating ICT as demonstrated by adequacy of digital content in the subjects taught by teachers, they allow learners in school interact with ICT tools in the classrooms for learning purpose, teachers prepare their lesson content by integrating ICT materials in their lesson, most teachers in schools have basic computer skills and ICT integration strategy is well understood by most teachers. The study further found out that a number teachers in public and private secondary schools were not competent in ICT integration in preparation of lesson materials using online resources, most of the teachers are not able to deliver lessons using power point projectors and a number of schools have not set adequate funds for integration process of ICT in teaching.

Ho: There is no significant relationship between public and private secondary teachers mean perception scores on ICT integration in Uasin Gishu County

Table 4: correlations between public and private secondary perception scores

\begin{tabular}{llll}
\hline $\begin{array}{l}\text { Mean perception score of teachers on } \\
\text { ICT integration }\end{array}$ & Rho- value & p-value \\
\hline Public schools & $\mathrm{N}=71$ & 0.208 & $0.002 * *$ \\
Private schools & $\mathrm{N}=71$ & 0.130 & 0.321 \\
\hline
\end{tabular}

** Correlation is significant at 0.05 level of significant

The test of hypothesis showed that we do not accept the null hypothesis and this implies therefore that there is a significant relationship between public and private secondary teachers mean perception scores on ICT integration in Uasin Gishu County.

\section{Conclusions of the study}

The study revealed that most of teachers in public and private secondary schools in Uasin Gishu County had favorable perceptions of availability of ICT infrastructure in their school. The study however, found out that in a number of schools in the county the computers and projectors were not available, supply of electricity was not reliable, the computers, projectors and videos were not in functioning condition and most of the computer labs had no internet facilities.

The study revealed that both private and public secondary teachers in Uasin Gishu County had favorable perceptions of availability of plans for ICT integration in teaching in their school. However, a number of schools in the county have no plans for integrating ICT in classroom instruction, schools do not strictly ensure that integration of ICT plans are adhered to, there are no adequate digital content on subject taught by teachers and schools have not set aside funds for the integration process of ICT in teaching. Therefore the study concludes that there is a significant relationship between public and private secondary teachers mean perception scores on ICT integration in Uasin Gishu County

The study further found out that private and public secondary 
teachers in Uasin Gishu County are generally competent in integrating ICT as demonstrated by adequacy of digital

content in the subjects taught by teachers, they allow learners in school interact with ICT tools in the classrooms for learning purpose, teachers prepare their lesson content by integrating ICT materials in their lesson, most teachers in schools have basic computer skills and ICT integration strategy is well understood by most teachers.

\section{Recommendations of the study}

1. The county Government of Uasin Gishu should provide ICT infrastructure in both private and public secondary schools. This can be achieved by partnering with the central government, school sponsors, parent association, donors and the communities that the schools serve.

2. The principals and school managers in Uasin Gishu County should develop ICT integration plans at the school level which should inform the process of integrating the same in classroom teaching and learning. They should ensure that the plans are strictly followed to integrate ICT in teaching.

3. The principals and school managers should facilitate capacity building of teachers on ICT integration. Through regular training programmes and seminars and workshops for both private and public secondary school teachers.

\section{References}

[1] Carrol, J.M.(1990). The Nurnberg< funnel. Cambridge,MA:MITpress. Retrieved from http:// instructiona on febuary 3.2018.

[2] Chigona, A. \& Chigona, W. (2010) An investigation of factors affecting the use of ICT for teaching in the western cape schools. Retrieved from web. Up.za./acis/ECIS2010/Content/paper/0097 on January 12, 2018.

[3] Elimu Network (2008). Information and communication Technology. Retrieved from http://kenya.elimu.net/secondary-teacher...ICT/ $\quad O N$ March 11,2018.

[4] Hennesy,S. \& Onguko,B. (2010). Key past and current initiatives supporting the use of ICT in schools in African commonwealth countries. Retrieved from ernwaca.org/panaf/spip.php on February 12,2018.

[5] Kenya. Ministry of information \&communication (2006). National information \& Communication (ICT) policy.

[6] Mukubwa, J. (2009). Eighty percent of primary school teachers' computer illiterate. Education news, 105 (June 17issue). Nairobi shrend publisher's Ltd.

[7] Sherri, L.J. (2010). Research methods ( $2^{\text {nd }}$ Ed). Belmont, C.A: Wassworth/ Cengage

[8] Sanja, M. M..,Mneria E., Ogoti. E.O.,Tenge,E.,\& Nasiuma, B.(2014). Investigation of Information Communication Technology in Kenyan Primary Education Sector. Vol. 5, No. 7 July 2014.Journal of Emerging Trends in Computing and Information
Sciences.

[9] UNESCO. (2008). ICT competency standards for teachers: policy framework. Retrieved from w.w.w.unesco.org/new/en/communication on March 10, 2018 